\title{
Evaluation of self-medication patterns among under-graduate medical students of Adichunchanagiri institute of medical sciences, Karnataka, India: a cross-sectional questionnaire-based study
}

\author{
Shwetha Shivamurthy, Ravi Shankar Manchukonda*, Deepika Gurappanavar
}

\begin{abstract}
Department of Pharmacology, Adichunchanagiri Institute of Medical Sciences, B.G. Nagar, Karnataka, India
\end{abstract}

\section{Received: 24 March 2016}

Accepted: 27 April 2016

*Correspondence to:

Dr. Ravi Shankar Manchukonda, Email: ravipharmac

@yahoo.com

Copyright: (C) the author(s), publisher and licensee Medip Academy. This is an openaccess article distributed under the terms of the Creative Commons Attribution NonCommercial License, which permits unrestricted noncommercial use, distribution, and reproduction in any medium, provided the original work is properly cited.

\begin{abstract}
Background: Self-medication is the treatment of common health problems with medicines that are taken on patient's own initiative or on advice of a pharmacist, without professional supervision. It is now becoming a common practice in many countries mainly due to lack of access to health care, easy availability of OTC (over the counter) drugs in market and poor drug regulatory practices. It assumes special significance among medical students as they are aware of the available medications.

Methods: A cross-sectional questionnaire based study was done from among undergraduate medical students, Adichunchanagiri institute of medical sciences (AIMS), BG Nagar, Karnataka, India. A structured questionnaire was given to medical students of all 4 years. Consent was taken from the students.

Results: Our results showed that $66 \%$ of the AIMS undergraduate students practiced self-medication. Paracetamol (40.8\%) was the most common selfmedicated drug followed by antihistaminics (20.2\%), antimicrobial drugs $(8.1 \%)$, analgesics $(7 \%)$ and others. Fever $(33.2 \%)$ was the most common illness for opting self-medication followed by upper respiratory tract infection $(23.1 \%)$, headache $(17 \%)$, allergy $(6.64 \%)$, diarrhea $(6.3 \%)$, menstrual pain $(2.53 \%)$ and others. Most common reason for opting self-medication was the illness being too trivial.

Conclusions: The prevalence of self-medication among medical students is high, facilitated by the easy availability of drugs and information from textbooks or seniors. A significant number of students were unaware of the adverse effects of the medications that they themselves take and suggest to others. Therefore, potential problems of self-medication should be emphasized to the students.
\end{abstract}

Keywords: Self-medication, Undergraduate medical students, OTC, Crosssectional questionnaire based study, Adverse effects

\section{INTRODUCTION}

Self-medication can be defined as obtaining and consuming drugs without the advice of a physician for diagnosis, prescription or surveillance of treatment. ${ }^{1,2}$ Self-medication differs from self-care in that it involves drugs that may do good or cause harm. ${ }^{3}$ In several studies it has been found that inappropriate self-medication causes wastage of resources, increases resistance of pathogens and generally causes serious health hazards such as adverse drug reactions, prolonged suffering and drug dependence. ${ }^{3-6}$
There are many reasons for the increased likelihood of self-medication among medical students. ${ }^{3}$ These students have easy access to information from drug indices, literature, and other medical students to self-diagnose and self-medicate. In addition, they have easy access to the medication itself through physician samples provided by pharmaceutical representatives and "the white coat" guarantees trouble free access to drugs available in pharmacies. There is a paucity of studies on selfmedication among medical students. ${ }^{3}$ The present study was undertaken to identify the reasons for, and the patterns of self-medication among medical students. 
In a study of self-medication in young Norwegian doctors, $56 \%$ of hospital physicians and the general practitioners reported self-medication during the previous year. ${ }^{5}$ A quarter of the primary healthcare professionals in Brazil self-medicated themselves. ${ }^{7}$ Self-medication with antibiotics was reported by $53 \%$ of doctors in a study from Karnataka state of India. ${ }^{8}$ Studies revealed that the increase in self-medication was due to a number of factors. These included socioeconomic factors, lifestyle, ready access to drugs, the increased potential to manage certain illnesses through self-care, and greater availability of medicinal products. ${ }^{9}$

The objective of our study was, therefore, to assess the self-medication practice, assess common types of illnesses, and identify frequently used drugs and determinants of self-medication.

\section{METHODS}

A cross-sectional study was carried out among the undergraduate students of Adichunchanagiri institute of medical sciences. A pre-designed semi-structured questionnaire was used to collect the relevant information pertaining to the study variables.

The questionnaires were distributed to the undergraduate medical students from the $1^{\text {st }}, 2^{\text {nd }}, 3^{\text {rd }}$ and $4^{\text {th }}$ years after obtaining consent from the students. The students were briefed on the aims and objectives of the study. The study subjects were informed that the information collected would be anonymous and participation would be totally on a voluntary basis.

The age, sex, and year of study were noted. The information regarding.

- Type of medication

- Type of illness for which the medication was used

- Reason for not consulting a doctor

- Their attitude toward self-medication

- $\quad$ Source of information and

- Awareness of side effects was recorded.

238 students consented for the study out of 250 students and filled in the questionnaire. 20 incomplete questionnaires were excluded and the remaining 218 were analysed. The questionnaires were assessed for their completeness and only the completed questionnaires were considered for the final analysis.

The approval for the study was obtained from the institutional ethics committee of Adichunchanagiri institute of medical sciences, BG Nagar, Karnataka, India prior to the commencement of the study.

\section{Statistical analysis}

Results were expressed in numbers and percentage.

\section{RESULTS}

Our study showed that $66 \%$ students of AIMS practiced self-medication. Female students $(75 \%)$ outnumbered males $(25 \%)$.

Table 1: Drugs used by the students for self-medication.

\begin{tabular}{|ll|}
\hline Drugs & Percentage \\
\hline Paracetamol & 40.8 \\
\hline Antihistamines & 20.2 \\
\hline Antimicrobials & 8.1 \\
\hline Analgesics (other than aspirin) & 7 \\
\hline Antacids & 5.4 \\
\hline Anti diarrheals & 5.4 \\
\hline Cough syrups & 4 \\
\hline Anti-emetics & 3 \\
\hline Anti spasmodics & 1.68 \\
\hline Mefenamic acid & 1.35 \\
\hline Aspirin & 1.35 \\
\hline Migrasse (anti-migraine drug) & 1.35 \\
\hline Albendazole & 0.67 \\
\hline Vitamin C & 0.67 \\
\hline Bisacodyl & 0.3 \\
\hline Fluticasone & 0.3 \\
\hline
\end{tabular}

Table 2: Illnesses for which self-medication was taken.

\begin{tabular}{|ll|}
\hline Illness & Percentage \\
\hline Fever & 33.2 \\
\hline Upper respiratory tract infections & 23.1 \\
\hline Headache & 17.08 \\
\hline Allergies & 6.64 \\
\hline Diarrhea & 6.3 \\
\hline Gastritis & 4.4 \\
\hline Menstrual pain & 2.53 \\
\hline Nausea and vomiting & 1.58 \\
\hline Migraine & 0.9 \\
\hline Aphthous ulcers & 0.9 \\
\hline Worm infestation & 0.63 \\
\hline Malaise & 0.63 \\
\hline Motion sickness & 0.3 \\
\hline Constipation & 0.3 \\
\hline Acne & 0.3 \\
\hline
\end{tabular}

Table 3 :Reason for self-medication.

\begin{tabular}{|ll|}
\hline Reason for self medication & Percentage \\
\hline Mild nature of the illness & 72.8 \\
\hline Time saving & 3.7 \\
\hline Sufficient academic knowledge & 21.2 \\
\hline others & 2.1 \\
\hline
\end{tabular}


Table 4: Attitude towards self-medication.

\begin{tabular}{|ll|}
\hline Attitude & Percentage \\
\hline Part of self-care & 91.9 \\
\hline Continue with self-medication & 2.6 \\
\hline Advise self-medication to friends & 5.3 \\
\hline
\end{tabular}

\section{DISCUSSION}

The practice of self-medication is widespread all over the world especially urban and educated population. ${ }^{9,10}$ Doctors also tend to self-medicate to the extent feasible due to their knowledge about diseases and drugs. Several studies have reported prevalence of self-medication varying from 25-56\%. ${ }^{5,11}$ Medical students acquire knowledge of drugs and skills of drug selection and prescribing during the undergraduate training which includes internship in many countries including India. It is also known that this group starts relying on selfmedication during their formative years of undergraduate training. Some studies have reported prevalence and pattern of self-medication in medical students with varying results. ${ }^{7,12}$

Our results suggest a high prevalence (68\%) of selfmedication in our students which is lower than reported by Badiger et al reporting $92 \%$ prevalence in a study of 200 students. ${ }^{13}$ In our study it was found that more female students $(75 \%)$ practice self-medication than male students $(24.8 \%)$. Similar observations were made in studies from India and abroad.

Previous prescriptions for the same illness were reported as the most common source of information about the drugs used for self-medication in the present study, which was similar to observation made in Tamil Nadu and Uttar Pradesh. However, in another study from India, and Ethiopia textbooks were reported as the most common source of information. ${ }^{12-15}$

Most common reason for analgesic self-medication reported by our students was the illness being too trivial (Table 3). Similar observations were reported in a previous study in North West Ethiopia, the most common reported factors for self-medication were low severity of symptoms. ${ }^{17}$ Fever $(33.2 \%)$ was the most common illness which prompted for self- medication in our study followed by upper respiratory tract infection $(23.1 \%)$, headache $(17.02 \%)$, allergy $(6.64 \%)$, diarrhoea $(6.3 \%)$, gastritis $(4.4 \%)$, vomiting $(1.58 \%)$, menstrual pain $(2.53 \%)$, migraine $(0.9 \%)$ worm infestation, malaise $(0.63 \%$ each $)$, constipation, sinusitis, acne and motion sickness (0.3\% each) (Table 2) . However, the most prevalent symptoms reported in the previous study in North West Ethiopia were cough and cold followed by fever and headache. ${ }^{14}$

Paracetamol (40.8\%) was the most common drug being used in our study followed by antihistamines (20.2\%), cetirizine being the most common drug, antimicrobials
$(8.1 \%)$, antacids and antidiarrheals $(5.4 \%)$, anti-emetics (3\%), cough syrups $(4 \%)$, antispasmodics (1.68\%) aspirin and migrasse $(1.35 \%)$, albendazole, vitamin $\mathrm{C}(0.67 \%)$, bisacodyl and fluticasone $(0.3 \%)$ (Table 1$)$.

Despite studying in detail about drug reactions, $41.5 \%$ of the students were unaware of the adverse effects of the drugs they used for self-medication. $58 \%$ of respondents were aware of the adverse effects associated with selfmedication as compared to just above $30 \%$ in the study by Badiger et al. ${ }^{13}$

$15.4 \%$ of the study group reported experiencing adverse effects, for which they either consulted a doctor or stopped the medication. In the present study $91.9 \%$ of the participants felt that self-medication was part of self-care (Table 4) which was higher to that reported in studies from Ethiopia and Karachi. ${ }^{16,17}$

\section{CONCLUSION}

This descriptive study has found that self-medication was very common among undergraduate medical students, facilitated by the easy availability of drugs, information from textbooks/seniors and previous prescriptions. A significant number of students were unaware of the adverse effects of the medication that they themselves take and suggest to others. Since inappropriate selfmedication has the potential to cause serious harm not only to the students themselves but also to those whom they suggest medication, potential problems of selfmedication should be emphasized to the students.

\section{ACKNOWLEDGEMENTS}

The authors are grateful to the undergraduate students of Adichunchanagiri institute of medical sciences, B.G. Nagar Karnataka, India for having whole heartedly participated and given their time for the study.

\section{Funding: Adichunchanagiri Institute of Medical Sciences Conflict of interest: None declared \\ Ethical approval: The study was approved by the Institutional Ethics Committee}

\section{REFERENCES}

1. Shankar PR, Partha P, Shenoy N. Self-medication and non-doctor prescription practices in Pokhara valley, Western Nepal: a questionnaire-based study. BMC Fam Pract. 2002;3:17.

2. Montastruc JL, Bagheri H, Geraud T, Lapeyre Mestre M. Pharmacovigilance of self-medication. Therapie.1997;52:105-10.

3. James H, Handu SS, Khalid AJ, Khaja A, Otoom S, Sequeira RP. Evaluation of the knowledge, attitude and practice of self-medication among first-year medical students. Med Princ Pract. 2006;15:270-5.

4. Hughes CM, McElnay JC, Fleming GF. Benefits and risks of self-medication. Drug Saf. 2001;24:1027-37. 
5. Hem E, Stokke G, Tyssen R, Grønvold NT, Vaglum $\mathrm{P}$, Ekeberg O. Self-prescribing among young Norwegian doctors: a nine-year follow-up study of a nationwide sample; BMC Med. 2005;3:16.

6. Kiyingi KS, Lauwo JAK. Drugs in home: danger and waste. World health forum. 1993;14:381-4.

7. Graciela ET, Castro SA, Oppelt AM, Petrini RM, Pereira IV, Sassi BT. Working conditions and selfmedication among primary healthcare professionals in an urban area of Pelotas, RS. Rev bras Epidemiol. 2007;10:66-74.

8. Nalini GK. Self-medication among allopathic medical doctors in Karnataka, India. BJM. 2010;3:325.

9. World health organization. The role of pharmacist in health care system; 1998.

10. Lam CL, Catarivas MG, Munro C, Lauder IJ. Selfmedication among Hong Kong Chinese. Soc Sci Med.1994;39:1641-7.

11. Sanghani S, Zaveri HG, Patel VJ. Self-medication: prevalence and pattern in urban community. J Pharmacovigilance Drug Safety. 2008;5:95-8.

12. Gupta YK. Popularity of self-medication among medical students, AIIMS. Available at www.INDIAedunews.net. Accessed 24 March 2016.
13. Abay SM, Amelo W. Assessment of self-Medication practices among medical, pharmacy, and health science students in Gondar University, Ethiopia. J Young Pharm. 2010;2:306-10.

14. Badiger S, Kundapur R, Jain A, Kumar A, Pattanshetty S, Thakolkaran N, et al. Self-medication patterns among medical students in South India. Australas Med J. 2012;5:217-20.

15. Abula T, Worku A. Self-medication in three towns of North West Ethiopia. Ethiop J Health Dev. 2001; $15: 25-30$

16. Gutema GB, Gadisa DA, Kidanemariam ZA, Berhe DF, Berhe AH. Self-medication practices among health sciences students: The case of Mekelle University. J Appl Pharmaceutical Sci. 2001;01(10):183-9.

17. Zafar SN, Syed R, Waqar S, Irani FA, Saleem S. Prescription of medicines by medical Students of Karachi, Pakistan: a cross-sectional study. BMC Public Health. 2008;19:162.

Cite this article as: Shivamurthy $S$, Manchukonda RS, Gurappanavar D. Evaluation of self-medication patterns among under-graduate medical students of Adichunchanagiri institute of medical sciences, Karnataka, India: a cross-sectional questionnairebased study. Int J Basic Clin Pharmacol 2016;5:9658. 